\title{
Ecotourism - model of sustainable tourist development
}

\author{
Mirela Ştefănică, „Al. I. Cuza” University of Iasi, Romania \\ Maria Vlavian-Gurmeza, „Al. I. Cuza” University of Iasi, Romania
}

\begin{abstract}
In the last years, the tendency in the tourism industry was that of return towards nature and towards the authentic cultural values. Among all the forms of tourism, ecotourism distinguishes itself through the strongest connection with the natural and cultural environment, representing the most valuable form of manifestation of sustainable tourism, with the fastest growth rhythm worldwide.

Integrated in the sustainable development, ecotourism involves activities that directly contribute to the nature protection and to keeping the old human creations unaltered.
\end{abstract}

\section{Keywords}

Ecotourism, sustainable development, sustainable tourism, environment, conservation, local population, SWOT analysis

\section{JEL Codes: Q 56}

\section{General considerations regarding Ecotourism}

Currently, ecotourism is also known under the name of "green tourism", "kind tourism", soft tourism" or "ecological tourism". In reality, under these denominations are hidden nuances of the concept.

Therefore, some authors consider that ecotourism refers to traveling in the natural, relatively unaltered, even wild areas, to admire the landscape and enjoy the world of plants and animals in their entire freedom, while other authors regard ecotourism as a form of tourism that has as main motivation observing and studying nature and the local traditions within a reservation. ${ }^{12}$,

Partially accepting these points of view, according to the author Vasile Glăvan, we consider that ecotourism does not have a restrictive addressability, for certain areas only, since the entire tourism activity must take place according to ecological principals. Currently, the tourists are more and more interested to travel to areas distinguished through the best quality of the environment components. They are preoccupied with the quality of air, water, vegetation, as a tourism resource, with the state of conservation of spiritual goods, the degree of safety offered in all the moments of the travel.

For these reasons, the tourism resources from each country and area of the world must be carefully protected, in order to be used in the future with the same profitability as at present. ${ }^{3}$

1 Glăvan, V. (2003), Turism rural. Agroturism. Turism durabil. Ecoturism (Rural tourism. Agrotourism. Sustainable tourism. Ecotourism) Ed. Economică, Bucharest, p. 169

2 Bran, F., Simion, T., Nistoreanu, P.(2000), Ecoturism (Ecotourism) Ed. Economică, Bucharest, pp. $15-18$

${ }^{3}$ Niță, M., Niță, C., Niță, I. (2008), Ecoturism în spațiu rural (Ecotourism in the rural space) in Talabă I. (coord.), Turismul rural românesc:actualitate şi perspective (The Romanian Rural Tourism: actuality and pesrpectives), Ed. Performantica, Iaşi, p. 108 
Regarding the definition of the notion of ecotourism, according to the opinion of the specialist Hector Ceballos-Lascurain, the one who was credited for introducing the ecotourism term" ${ }^{4}$, the definition is: "a travel in natural and uncontaminated quiet natural areas having as specific object studying, admiring and enjoying watching their landscapes, animals and plants as any cultural manifestation (at the same time old and present) carried out in these areas." As a result, ecotourism focuses on learning activities and nature discovery.

Another author, Fennell (2001) defines ecotourism as a "form of sustainable tourism, based on natural resources, which is mainly focused on the direct contact with nature and with acquiring knowledge about nature and which must have a low impact on the environment, without consumes, oriented towards the welfare of local communities (control capacity, benefits, dimensions). It covers natural areas and must contribute to conserving or protecting them."

In the majority of definitions given to ecotourism, encountered in the specialty literature, we noticed two main elements: the fact that it is based on nature and at the same time on value (sustainable).

\section{Elements involved in the development of ecotourism}

Ecotourism supposes carrying out the tourism activities in an environment with landscapes unaltered by pollution and at the same time reassuring. It represents a model of sustainable exploitation of the tourism resource, due to the minimizing of the negative effects on the environment.

Figure 1. emphasizes the elements involved in developing ecotourism.

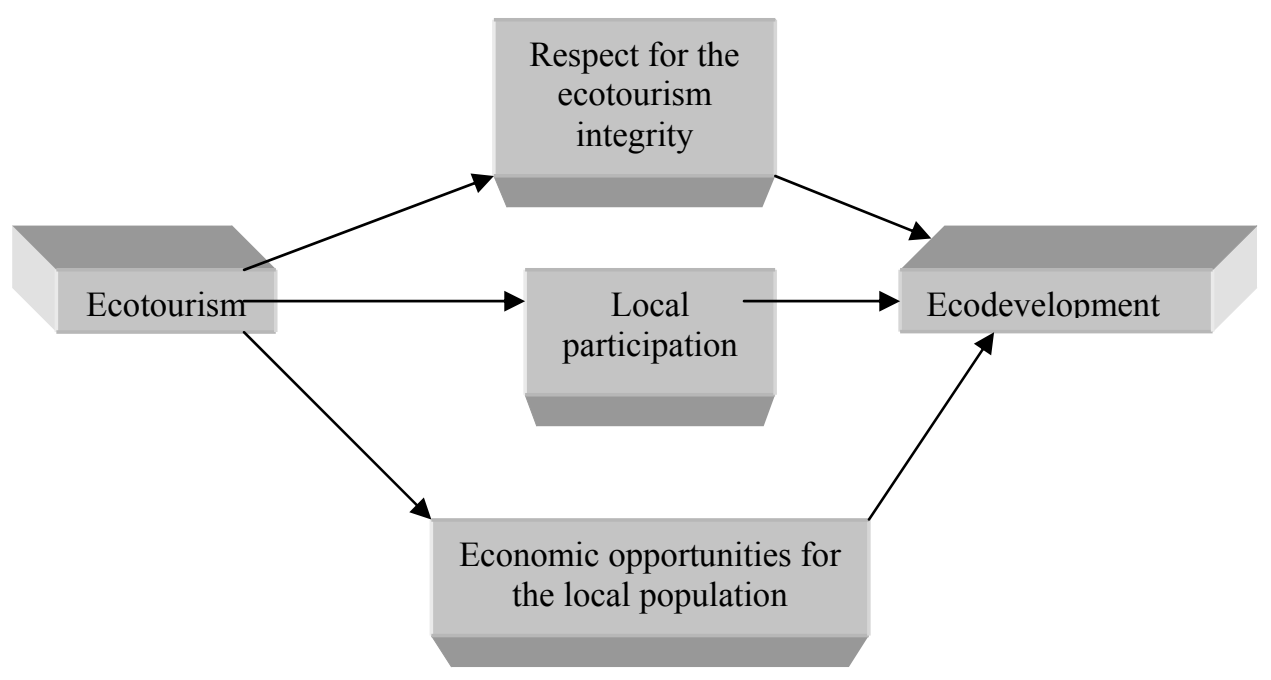

Figure. 1. The elements involved in the ecotourism development

Source: F. W. Theobald (1998), Global Tourism, Butterworth Heinemann, GreatBritain, pg.201

The first elements involved in the ecotourism development, the respect for the ecosystem integrity, aims at emphasizing the importance of the environment in supporting tourism, maintaining the level of development at a small scale under the control and under the local management, using a specific local development, the compatibility of the development plan

${ }^{4}$ Băltărețu, A.,M. (2007), Ecoturism şi dezvoltare durabilă (Ecotourism and sustainable development) Ed. Pro Universitaria, Bucharest, p.104 
with the environment, using materials, know-how and local working force, using facilities and equipments which conserve the energy, practicing the recycling, capitalization and national use of resources, preserving vegetation, reducing the deforestations, using alternative, sustainable technologies ${ }^{5}$.

Local participation, the second important element for developing ecotourism, aims at promoting the local participation as much as possible, creating opportunities for the host population, the transfer of property to the local community and its administration, creating opportunities for the group projects and local population as regards the control and administration of natural valuable resources, stipulating some alternative local measures, promoting the socio-cultural "pride" through the organization of programs by the local community, complying with the local ideology and inheritance, stipulating opportunities for the interaction between the local population and visitors.

Regarding the third element involved in developing ecotourism, respectively economic opportunities for the local community, they refer to coordinating all the elements with the purpose of optimizing the benefits of the local economy, creating jobs for the host population, guaranteeing and protecting the local population, including the communities' ideas in the political decisions, the equitable distribution of the economic benefits, recognizing the local efforts/services, using the local materials and working force to keep the money into the local economy, keeping a decentralized management ${ }^{6}$ etc.

In all the tourism regions on the globe, the ecotourism development mainly aims at four aspects:

Economic, ecological, social and cultural, aspects emphasized through table 1.

Table no. 1. The main aspects of ecotourism

\begin{tabular}{|c|c|c|}
\hline \multirow{4}{*}{$\begin{array}{l}\text { The main } \\
\text { aspects of } \\
\text { ecotourism }\end{array}$} & Economic & $\begin{array}{l}\text { - Increasing the degree of capitalization of } \\
\text { resources, especially the least known ones in order } \\
\text { to achieve a reduction of the pressure exerted on } \\
\text { the intensely exploited resources }\end{array}$ \\
\hline & Ecological & $\begin{array}{l}\text { - Reducing and eliminating waste - if possible } \\
\text { recycling them; a more rational use of all the } \\
\text { resources }\end{array}$ \\
\hline & Social & $\begin{array}{l}\text { Maintaining some occupations, traditional } \\
\text { professions of the inhabitants in the areas, which } \\
\text { determine the increase of the number of jobs by } \\
\text { attracting the population into practicing different } \\
\text { forms of tourism }\end{array}$ \\
\hline & Cultural & $\begin{array}{l}\text { - Capitalizing the civilization, art and culture } \\
\text { elements that express a certain cultural identity } \\
\text { and which develop the spirit of tolerance }\end{array}$ \\
\hline
\end{tabular}

We can say that ecotourism represents the future of tourism only if combined with a rational, strong planning and management. It helps promoting actions for improving nature, the social, the cultural and the economic, for supporting the conservation efforts.

By ecotourism, the tourists are culturalized through their involvement in direct experiences, and the ecological education of all the categories involved in the tourism activities (local community, governmental and non-governmental organizations and economic agencies).

Regarding ecotourism, OMT adopted a strategy that mentions the following ${ }^{7}$ :

\footnotetext{
${ }^{5}$ Theobald F.,W. (1998), Global Tourism, Butterworth Heinemann, Great Britain, p. 200

${ }^{6}$ Idem

${ }^{7}$ www.wto.org
} 
- The theories that ecotourism is based on must be part of the tourist patrimony of the planet, being considered of world interest; the territories with traditional life styles of the local populations must be respected with a special rigor;

- By ecotourism we are aiming at minimizing the negative effects on the local and natural environment, and on the local population as well.

- Ecotourism contributes to administering the protected spaces and improving the relationship between the local communities and the persons authorized to administer these protected spaces;

- Ecotourism favors an interaction between the host population and the tourists, determining a real interest for a sustainable development and protection of the natural area, both in the states which provide tourists and in the hosting countries;

- Ecotourism supposes extending the specter of traditional economic activities (Agriculture, breeding of animals, fishing), without replacing them however;

- The local populations and the employees in the tourism industry must use the natural spaces in a sustainable manner and appreciate the natural and cultural valuable objectives.

Therefore we ascertain that the main objective that ecotourism proposes is supplying a high quality tourism in the conditions of protecting the natural areas, involving the host population and stimulating the local economies. We consider that these desiderates can be achieved by increasing the resources found in conservation, by achieving the environment education and involving the local authorities.

\section{The SWOT analysis of the Romanian tourism}

At the national level, ecotourism is at an incipient stage characterized through the existence of ecotourism "nuclei" in different areas of the country. An important factor for supporting the ecotourism activities is represented by the increased interest for this type of activity. An increasing number of tourists tend to practice ecotourism and want to get involved in this sense, into nature conserving actions, for appreciating and promoting the traditional way of life, the valuable customs and traditions.

Romania has a huge potential as regards ecotourism, since it has the highest density of large carnivores from Europe (half the continental population of bears, a third of the wolves and a third of lynxes), pastoral villages and towns, extended fields, the Danube Delta (hosting 60\% of the total population of dwarf cormorants at the world level).

From the beaches of the Black Sea to the skiing and mountain hikes and tourism based on nature in the Danube Delta, the natural patrimony of Romania offers unlimited opportunities for tourists, in general and ecotourism, especially. We have the seventh part of the world cultural inheritance sites, including the painted monasteries in Bucovina, the historical citadel of Bucovina, the Dacian citadels of Orăştie Mountains, Transylvania, a famous world because of its association with the legend of Dracula. The multitude of architectonic styles and the rich literary history are reflected in an ethnic mixture of Romanians, Hungarians, Ukrainians, Russians and Turkish. A different and unique population like the country landscapes together with a rich history offers the visitors an incursion into the present and past of Europe.

In table 2, we present the SWOT analysis for the ecotourism in Romania.

Table NO. 2 The SWOT analysis for the ecotourism in Romania

\begin{tabular}{|c|c|}
\hline STRONG POINTS & WEAK POINTS \\
\hline - The diversity of natural tourism \\
$\begin{array}{l}\text { resources (relief and special } \\
\text { landscapes), wild areas unaffected }\end{array}$ & $\begin{array}{l}\text { The lack of a unitary system for } \\
\text { administering the protected areas that } \\
\text { allow to practice ecotourism in these }\end{array}$ \\
\hline
\end{tabular}


by the man's intervention;

- The existence of a large number of protected areas (national, natural parks and reservations) included in the European network the Nature 2000 ;

- The Biodiversity present in all the areas - special flora and fauna (the population of large carnivores is recognized at the national and international level), with unique species in Europe;

- The existence of some tourism objectives included on the list of UNESCO world patrimony (the monasteries with an exterior fresco) situated in the parks;

- Traditional manner of life and agricultural practices;

- Developing the capacity of accommodation in the agrotourism pensions;

- The existence of important mineral sources both from the quantitative point of view and as regards the facilities offered by the balneo-climatic resorts;

- The diversity of ecological agroalimentary products;

- Reduced pollution in the majority of rural areas;

- Traditional cuisine and regional specialties;

- The existence of an ethnographic and folkloric thesaurus of great originality with a rich calendar of traditional fairs and folkloric manifestations for the entire duration of the year;

- The traditional architecture and the special aspect of the countryside households from different areas of the country. areas;

- Reduced level of education of tourists and the population in the rural environment in view of practicing ecotourism;

- Insufficient exploitation of the natural ad historical monuments;

- The treatment units afferent to balneary resorts have a high degree of attrition and non-adaptation to the European standards;

- The lack of an organized system of indicators for the tourism objectives and itineraries;

- Overexploitation of natural resources through inadequate grazing, land clearing, poach, uncontrolled tourism;

- The public transport to the tourism objectives is insufficiently organized and promoted;

- The cost of flights to Romania is high compared to other countries;

- The decrease of the number of foreign tourists who visit our country;

- The reduced use of the accommodation capacity $(27.2 \%)$ and the duration of sojourn in the country in relation with the existent tourism potential;

- The insufficient development/exploitation of the recreation infrastructure;

- Low degree of the population occupied in tourism and the reduced training level of the guides from the ecotourism/specialty personnel who administers the accommodation structures;

- The absence of a fair in ecotourism;

- The inefficient ecologization of tourism areas;

- The lack of strategies that ensure the promotion of ecotourism in the protected areas.

\section{OPPORTUNITIES}

- High international interest for ecotourism, agrotourism, rural tourism, adventure tourism;

- Very good perspectives for exploiting the mountain areas for the entire duration of the year by hiking, equitation, alpinism, extreme sports, ski;

\section{THREATS}

- Strong competition at the destination level - external tourism destinations at similar prices and superior conditions;

- Degradation of the protected areas through the irrational exploitation of the natural resources and the non-ecological and irresponsible tourism;

- The infrastructure of utilities (water, 
- The climate, with soft winters and cold summers, favorable for the tourist activity during the year;

- The increase of the number of tourists who have ecotourism as motivation;

- Implementation of tourism infrastructure projects by the local administration in some regions;

- The existence of international airports near areas of interest for ecotourism;

- The existence of a basic research, development and innovation infrastructure;

- The possibility to attract tourists and foreign investors by improving the cities' image, exploiting the historical, cultural, spiritual and traditional inheritance;

- Promoting some events based on "nature calendars" (the groan of deer, the blossoming of the mountain peony etc.)

- The existence of raw materials (construction and wood materials) capable to attract foreign investors;

- The possibility for the airports to support the business environment and become starting point for the tourism itineraries, through the airports modernization;

- The forest regime, legally regulated, can have favorable effects on the environment and tourism;

- The existence of the legislative framework which allows the development of the protected areas and their conservation;

- The presence of webs in ecotourism within the Internet network. sewage, waste management) inexistent or weakly developed in the rural areas;

- The transport infrastructure not adapted to the community standards;

- The inadequate image of Romania can affect its choice as a tourism destination;

- The urbanization of rural population involving the lost of authenticity and the local specificity;

- The lack of awareness regarding the role of introducing an environmental management system in the tourism sector;

- The existence of some areas predisposed to natural disasters (floods, landslides)

- The migration of the working force abroad;

- The continual growth of the poverty degree in some important regions for ecotourism;

- Loss of customs and traditions;

- Extending the built-up areas in the immediate neighboring areas of the protected natural areas;

- The instability of the national currency;

- Precarious emergency medical services;

- Economic changes on the international plan;

- The intensification of the economical financial crisis.

As a conclusion, we consider that practicing ecotourism, as an integrant part of the sustainable tourism development, is the most beneficial path to follow, apt to ensure a safe and unaltered environment, especially for the future generations. In this context, it represents a process whose development can be achieved without the degradation or exhausting of resources that make the existence of life on earth possible. 


\section{Bibliography}

1. Băltărețu, A.,M. (2007), Ecoturism şi dezvoltare durabilă (Ecotourism and sustainable development), Ed. Pro Universitaria, Bucharest

2. Bran ,F., Simion, T., Nistoreanu, P. (2000), Ecoturism (Ecotourism), Ed. Economică, Bucharest

3. Glăvan, V. (2003), Turism rural. Agroturism. Turism durabil. Ecoturism (Rural tourism. Agrotourism. Sustainable tourism. Ecotourism), Ed. Economică, Bucharest

4. Niță, M., Niță, C., Niță, I. (2008), Ecoturism în spațiu rural (Ecotourism in the rural space) in Talabă, I., Haller, A.,P., Talpaş, J., Turismul rural românesc: actualitate şi perspective (The Romanian rural tourism : actuality and perspectives), Ed. Performantica, Iaşi

5. Theobald, F.,W. (1998), Global Tourism, Butterworth Heinemann, GreatBritain

6. ***WTTC (2006), România. Impactul turismului şi călătoriilor asupra locurilor de muncă şi economiei (Romania. The impact of tourism and travels on the jobs and economy).

7. www.wto.org 